\title{
RESENHAS
}

\section{Reis negros coroados}

\section{José Roberto Pinto de Góes}

Mello e Souza, Marina de. Reis negros no Brasil escravista. História da festa de coroação de Rei Congo. Belo Horizonte, Editora da Universidade de Minas Gerais, 2002, ....p.

Referindo-se à festa de coroação de reis negros, realizada hoje em dia, Marina de Mello e Souza escreveu: "Mesmo que os seus significados básicos permaneçam os mesmos para os que a vivem anualmente, $o$ espaço que ocupava na sociedade como um todo se restringiu bastante, e para os que a olham de fora, ela se tornou manifestação folclórica, tradição admirada por alguns, mas percebida como deslocada no tempo." Há algo de comovente em alguma coisa tornar-se paulatinamente incompreensível, virar folclore e sucumbir ao tempo. Talvez por isso existam os historiadores. Veja-se o caso de Marina, que começou a entreter este livro ainda na época em que escrevia a dissertação de Mestrado, quando se inquietava por, em
Parati, haverem desaparecido as congadas e os jongos. Se não é possível, nem desejável, suspender o fluxo do tempo, serve de consolo o fato de que é possível resgatar o passado da incompreensão e da morte absoluta, configurada pelo pleno esquecimento. Ao menos enquanto a tabacaria continuar defronte da janela de Fernando Pessoa e existir a língua portuguesa e este planeta errante.

A festa de coroação de reis negros é o tema de Reis Negros no Brasil escravista. O livro, originalmente tese de Doutorado apresentada ao Programa de Pós-graduação da UFF, está organizado em cinco capítulos. No primeiro, a autora discute o significado do rei e de sua mise en scène, na Europa e na África. Nos dois seguintes, transporta o leitor para a África habitada por povos falantes de línguas bantos, nos séculos em que a história da região entrelaçou-se às portuguesa, européia e brasileira, durante os quais cerca de três milhôes e meio de africanos foram tra- 
zidos a povoar o Brasil. Os capítulos seguintes tratam da festa e de suas transformações.

O livro é uma importante contribuição à historiografia brasileira. Vem preencher uma lacuna sintomática, concernente ao acanhado espaço ocupado pela África na historiografia de língua portuguesa produzida no Brasil, ressalvado, claro está, a qualidade dos poucos estudos que se aventuram em território tão pouco explorado. A natureza sintomática da lacuna fica por conta do fato de que tal ausência, coisa estarrecedora, na verdade, não estarrece a ninguém: os nossos cursos de graduação em História, em boa parte, continuam ignorando o conselho de Von Martius, segundo o qual devíamos, os brasileiros, estudar as tradições européias e indígenas, mas também as africanas, de modo a compreender e escrever a nossa história. Permanecemos um tanto clones de Varnhagen, fascinados pelo que reinou e reina na Europa. A pesquisa sobre a festa levou a autora a um apurado estudo na bibliografia mais recente, inclusive a antropológica, concernente às culturas e sociedades localizadas na África Centro - Ocidental, pertencentes a um tronco lingüístico co- mum, o banto. $\mathrm{O}$ resultado foi um painel abrangente da história e das tradições culturais de inúmeros povos e sociedades que tiveram um papel decisivo na formação do Brasil.

Acresce o mérito, o fato da África comparecer no livro, não na forma habitual, parece que "politicamente correta”, do continente indefeso ante a sanha cobiçosa do europeu. Em vez disso, o leitor é apresentado a uma região com uma história própria, a cujas características e vicissitudes os visitantes tiveram que se adaptar. Composta de sociedades complexas, com hábitos enraizados, inclusive no que diz respeito à compreensão do mundo e da vida, nas quais, aliás, a sanha cobiçosa de uns, de poder e de riqueza, não era menor do que a dos estrangeiros.

Exemplo disso é a história da cristianização do reino do Congo, com o qual os portugueses se depararam quando descobriram a embocadura do rio Zaire, no final do século XV. Os convertidos filtraram, a partir da rede de significaçôes que era peculiar à cultura bacongo, os ensinamentos e as esquisitices dos padres, criando um catolicismo muito particular, assentado sobre uma cosmogonia própria e inalterada. Nesta, os mundos natural e so- 
brenatural, dos vivos e dos mortos, eram reflexo um do outro e encontravam-se separados pela água ou por uma superfície que reflete a imagem projetada, como o espelho. No mundo de cá, vivia a gente negra, no qual aparecia pelo nascimento e desaparecia com a morte; no mundo dos mortos (que eram brancos) habitavam os ancestrais e espíritos diversos, que influenciavam o mundo visível, diretamente ou através de líderes religiosos (itomi e nganga, em kikongo). Se dependesse apenas da vontade benevolente do criador, a vida seguia boa e em harmonia. Mas forças malévolas, despertadas, conscientemente ou não, pelos homens, faziam da vida o que ela era, sujeita a doenças, pobreza, desavenças e demais infortúnios. Por isso era muito importante poder comunicar-se com o mundo dos espíritos e tentar refazer a ordem natural das coisas.

Movimentos religiosos surgiam toda vez que os cultos tradicionais se mostravam ineficazes. Calcula-se que os mais longevos duravam uns 50 anos. Freud dizia que a religião é o delírio das massas. Se assim for, cada geração de africanos se via obrigada a dar novas roupagens ao delírio coletivo - o que não deixa de ser uma medida do quanto é difícil alcançar a paz e a harmonia no mundo dos vivos. $\mathrm{O}$ padrão era mais ou menos o mesmo. Um líder carismático convencia os demais que, em sonho ou em transe, comunicava-se com o além. Seguia-se a pregação e a aceitação das novas normas, que eram uma "recombinação de rituais, símbolos, crenças e mitos já existentes, sendo apenas ocasionalmente incorporado material completamente novo", no dizer de Marina. O processo envolvia a conversão de aldeias, lances dramáticos, ritos de purificação (algo análogo ao batismo cristão), a destruição de objetos cultuados (aos quais se dava o nome de minkisi), e a adoção de outros, quiçá pela incorporação de elementos estrangeiros. A recombinação de mitos e ritos se dava sempre nos limites daquelas crenças básicas, que o estudo mais autorizado sobre o assunto (Religious movements in Central Africa: a theoretical study, de Craemer, Vansina e Fox) denomina "complexo ventura - desventura". Os povos falantes do banto faziam isso há séculos, quando os portugueses descobriram o Zaire.

Os nossos ancestrais lusos também tinham lá o seu arrebatamento característico, muito parecido, em 
variados aspectos, com o que dava asas à imaginação no reino do Congo. Também acreditavam no mundo dos mortos e dos espíritos e na possibilidade de fazê-lo interceder por nós, viventes. (Às vezes, de inusitadas maneiras: e não havia gajas casadoiras que, impacientes, esfregavam a imagem do santo nas próprias coxas, com o intuito de convencê-lo a arranjar-lhe um marido?) Também tinham os seus rituais, os seus minkisi — basta pensar na profusão de santos cujas imagens são cultuadas pelos fiéis - e os seus nganga, os padres. Assim, mais uma vez nas palavras de Marina, "o cristianismo foi recebido pelos congoleses como um novo movimento religioso, excepcionalmente poderoso".

Quando, por ocasiāo do batismo do rei do Congo, o irmão dele afirmou ter encontrado uma cruz de pedra quando saía de casa, os padres viram nisso um sinal do triunfo de Cristo e, os congoleses, mais uma confirmação de seculares convicções - notadamente, o que a cruz representava na cosmogonia bacongo, na qual os mundos encontravam-se separados pela água ou pelo espelho. Uns viam o triunfo de Cristo onde outros viam a representação de en- sinamentos ancestrais. Lembra a carta de Caminha: "Isto tomávamos nós nesse sentido, por assim o desejarmos!" Durante um bom tempo as relações entre portugueses e congoleses pautaram-se por uma espécie de "diálogo de surdos", numa sucessão de "mal entendidos" mutuamente concertada. Aos padres como às elites congolesas convinha a "cristianização" do reino. Aos padres, pela sabida mescla de fé, cobiça e gosto pelo poder. Aos congoleses, pelos mesmos motivos. $\mathrm{O}$ catolicismo era um movimento religioso que impunha respeito: os cristão pareciam bafejados pela sorte, dominavam uma tecnologia superior (que incluía arma de fogo e escrita) e vinham de depois da grande água. Havia de conferir legitimidade ao rei — pois o soberano devia ser capaz de merecer a benevolência do outro mundo - e reforçar o seu poder.

O estudo da cristianização do reino do Congo é um momento importante da pesquisa sobre a festa da coroação de reis negros no Brasil, mas é apenas um dos temas abordados no livro, relativos à história da África. Ao situar o processo na história africana, Reis Negros no Brasil escravista convida o leitor a compreender a organização social dos 
povos bantos da região Centro Ocidental, as relações ambíguas entre linhagem e escravidão, o papel do tráfico transatlântico na história dos reinos do Congo, do Ndongo, de Matamba etc. (o leitor há de preferir conhecê-los pelas palavras da própria Marina).

Festas de coroação de reis negros aconteceram em Portugal, na América do Norte, no Caribe, na América espanhola, mas, sobretudo, no Brasil, onde existem desde o alvorecer do século XVII. Repare o leitor como Henry Koster assistiu a uma, em Recife, no ano de 1814:

No mês de março tem lugar a festa anual de Nossa Senhora do Rosário, dirigida pelos negros, e é nessa época que elegem o Rei do Congo, se a pessoa que exerce essa função faleceu durante o ano, resignou por qualquer motivo ou haja sido deposta por seus súditos... Esses soberanos exercem uma espécie de falsa jurisdição sobre seus vassalos, da qual muito zombam os brancos, mas é nos dias de festa que exercem sua superioridade e poder sobre seus companheiros. Os negros dessa nação mostram muito respeito para com seus soberanos... O negro velho que seria coroado nesse dia de festa, veio pela manhã cedo apre- sentar seus respeitos ao Vigário que lhe disse, em tom jovial: 'Perfeitamente, senhor, mas hoje estarei às suas ordens, devendo servir-lhe de Capelão!' Pelas onze horas fui à Igreja com o Vigário. Ficamos parados à porta, quando apareceu um numeroso grupo de negros e negras, vestidos de algodão branco e de cor, com bandeiras ao vento e tambores soando. Quando se aproximaram, descobrimos, no meio, o Rei, a Rainha e o Secretário de Estado. Cada um dos primeiros trazia na cabeça uma coroa de papel colorido e dourado. O Rei estava vestido com uma velha roupa de cores diversas, vermelho, verde e amarelo, manto, jaleco e calções. Trazia na mão um cetro da madeira, lindamente dourado. A Rainha envergava um vestido de seda azul, da moda antiga. O humilde secretário ostentava tantas cores quanto seu chefe, mas era evidente que sua roupa provinha de várias partes, umas muito estreitas, e outras demasiado amplas para ele. As despesas com a sagrada cerimônia deviam ser pagas pelos negros e por isso, no meio da Igreja, estava uma mesinha, com o tesoureiro dessa Irmandade preta e outros dignatários, e sobre ela uma pequena caixa para receber o dinheiro. Tudo ia lenta- 
mente, muito mais lentamente que o apetite do Vigário, que nada comera, embora fosse perto do meiodia, porque ele e outros padres assistentes deviam cantar a missa. Conseqüentemente, aproximou-se da mesa e começou a falar aos diretores, declarando que não iria ao altar antes que a despesa fosse paga. Divertia-me muito vê-lo cercado pelos negros e entediado pela falta de pontualidade nas suas contribuições. Houve a seguir um rumor na Igreja entre os pretos. O Vigário havia exprobrado alguns deles e logo que este os deixou, começaram a discutir uns com os outros, em voz alta e com palavras zangadas, sem respeito pelo local. Foi uma cena muito interessante para mim e para outras pessoas, mas tudo se passou rapidamente. Por fim, Suas Majestades ajoelharam-se ante a grade do altar-mor e a missa começou. Terminado, o novo Rei devia ser coroado, mas o Vigário estava com fome e desempenhou-se sem muitas cerimônias. Segurou a coroa, na porta da Igreja, o novo soberano apresentou-se e foi mandado ajoelhar, a insígnia lhe foi posta e o Vigário disse: 'Agora, senhor Rei, vai-te embora!'

A citação é longa mas a descrição da cerimônia é ótima. Observese a pobreza dos escravos na roupa do "humilde secretário", composta de peças diferentes, cujas medidas não eram as dele. $\mathrm{O}$ modo como os súditos e devotos levavam a cerimônia a sério, trocando, até, palavras zangadas entre si. $\mathrm{O}$ modo como os "brancos" zombavam dela, a começar pelo padre, impaciente por aplacar seus apetites. O próprio Koster divertiu-se muito, ao vê-lo rodeado de negros. Até agora, o que sobressaía na festa era o ser um ritual de inversão, comum em muitas sociedades, inclusive as portuguesa e baconga: breves instantes nos quais o mundo fica de ponta cabeça, o fraco vira forte, o forte vira fraco e o mar vira sertão. Marina propõe que a festa, além disso, celebrava um mito, o mito fundador de uma comunidade negra e católica no Brasil. Com todo direito às luzes de Mircea Eliade: a congada relembraria o tempo mítico no qual o caos se fez ordem e as coisas receberam nomes. Mito elaborado a partir da herança africana (aí incluída a idealização do passado), mas também de apropriações no universo simbólico dos senhores. Além, claro, da apetitosa propensão em reinventar uma identidade, em meio às agruras da escravidão.

Reis, coroas e cetros ajudavam a forjar identidades na África e con- 
tinuaram com a mesma valia no Brasil. A coroa podia ser de papel, mas isso não tinha importância. $\mathrm{O}$ vigário estava interessado nas economias dos escravos e de pança vazia. Quase se pode vê-lo, impaciente, na porta da igreja, a segurar uma coroa de papel dourado, prestes a assentála na cabeça de um velho escravo. Após ler o livro de Marina, pode-se imaginar também os assistentes, acompanhando a coroação do rei congo pelo nganga branco. Eram também protagonistas, pois não deixavam de estar coroando a si próprios. Diálogo de surdos.

Reis Negros no Brasil escravista é também um ótimo exemplo de como pode a História Cultural contribuir para a história das pessoas comuns, mesmos as mais oprimidas, como era o caso dos escravos. Pelo estudo de uma festa se escreve a história daquela legião de desterrados. $\mathrm{Na}$ celebração há histórias, significados, escolhas, além de muita esperança e ilusão. Como devia ser uma festa tipicamente lusitana. Aliás, tomara que o livro passe o óbito definitivo à idéia de que a escravidão anulava a "humanidade" do escravo. Nele, os escravos são surpreendidos na arte de recriar um mundo espiritual tão complexo como o de seus dominadores. Se a isso acrescentamos a lembrança de que o mundo material ficava a cargo do seu trabalho...

Para finalizar, cumpre dizer que o livro de Marina de Mello e Souza é também uma ótima contribuição à sociedade brasileira. As lembranças movem o mundo e a vida, e o trabalho do historiador é lembrar, como disse Hobsbawm. A geração presente, ao menos a parte dela que governa o Brasil, instruiu-se na crença de que os escravos eram um nada, ao invés de sujeitos da história. Era o efeito da transposição do diálogo de surdos para a historiografia e para a sociologia. O resultado, agora, é a tentativa de implantar cotas raciais no Brasil, uma maneira infinitamente mais sutil, só possível em tempos muito hipócritas (Caminha jamais acharia emprego hoje em dia), de discriminar e ser racista. Mas como tamanha sutileza só subsiste na ignorância, quem sabe o livro de Marina não pode ser antídoto a tais imposturas?

\section{Notas}

${ }^{1}$ KOSTER, Henry. Viagens ao Nordeste do Brasil. Secretaria de Educação e Cultura, Governo do Estado de Pernambuco, 1978, pp. 276-7. 